\title{
"A Mere Matter of Rock": Organized Labour, Scientific Evidence and British Government Schemes for Compensation of Silicosis and Pneumoconiosis among Coalminers, 1926-1940
}

\author{
MARK W BUFTON and JOSEPH MELLING*
}

\begin{abstract}
Methods and Models in the Historiography of Occupational Health
The growth of statutory compensation for industrial injuries and illness has attracted considerable attention from historians of state welfare and students of organized labour in both Europe and North America. ${ }^{1}$ The rights of legal redress for disease and accidents in the workplace have become the subject of some debate among historians of occupational health and safety, most particularly in regard to asbestos-related illnesses. ${ }^{2}$ Among the most detailed and scholarly accounts of the subject in Britain are those by Peter Bartrip and his collaborators. ${ }^{3}$ In contrast to many accounts in labour and medical history which
\end{abstract}

(C) Mark W Bufton and Joseph Melling 2005

* Mark W Bufton, PhD, Honorary University Fellow, and Joseph Melling, PhD, Centre for Medical History, SHiPSS, Amory Building, University of Exeter, Exeter, Devon, EX4 4RJ, UK.

M.W.Bufton@exeter.ac.uk; J.L.Melling@exeter.ac.uk

The research on which this article is based was generously funded by the Wellcome Trust. Thanks are due to Robert Turner and the staff of the University Archives, Swansea, for their assistance in gathering information. We are also grateful for helpful criticisms offered by the editors and referees of Medical History. The usual disclaimers apply.

The archives consulted for this paper are: the Public Record Office (hereafter PRO) at Kew, London; minutes of the meetings of the South Wales Miners' Federation (hereafter SWMF) and the Miners Federation of Great Britain (hereafter MFGB), held at the South Wales Miners Library (hereafter SWML); the South Wales Coalfield Collection (hereafter SWCC) held by the University of Swansea, Wales.

${ }^{1}$ E P Hennock, British social reform and German precedents: the case of social insurance, 1880-1914, Oxford, Clarendon Press, 1987; Roy Hay, The origins of the Liberal welfare reforms, 1906-14, 2nd ed., London, Macmillan, 1983; T Skocpol, States and social revolutions: a comparative analysis of France, Russia and China, Cambridge University Press, 1979; M Weir, A S Orloff and T Skocpol (eds), The politics of social policy in the United States, Princeton University Press, 1988; A de Swaan, In care of the state: health care, education and welfare in Europe and the USA in the modern era, Cambridge, Polity, 1988; P Baldwin, The politics of social solidarity: class bases in the European welfare state 1875-1975, Cambridge University Press, 1990.

${ }^{2} \mathrm{G}$ Tweedale, Magic mineral to killer dust: Turner \& Newall and the asbestos hazard, New York, Oxford University Press, 2000, pp. 26, 169, 245-8, 287, 288-9; P W J Bartrip, The way from dusty death: Turner and Newall and the regulation of occupational health in the British asbestos industry, 1890s-1970, London, Athlone Press, 2001; Ronald Johnston and Arthur McIvor, Lethal work: a history of the asbestos tragedy in Scotland, East Linton, Tuckwell Press, 2000, pp. 56, 147.

${ }^{3} \mathrm{P}$ W J Bartrip, Workmen's compensation in twentieth century Britain: law, history and social policy, Aldershot, Gower Publishing, 1987; P W J Bartrip and S B Burman, The wounded soldiers of industry: industrial compensation policy 1833-1897, Oxford, Clarendon Press, 1983. 


\section{Mark W Bufton and Joseph Melling}

express strong empathy with the plight of workers who faced injury and death in the workplace, Bartrip adopts a model of industrial behaviour which is closer to rationalchoice assumptions of mainstream economics. ${ }^{4}$ His recent account of government regulation of occupational diseases since the nineteenth century offers limited comment on the attitudes of trade unionists to accidents, though he broadly maintains that British unions have historically been more concerned with winning compensation awards than pressing for the prevention of hazards in the industrial workplace. ${ }^{5}$

The role of the Home Office within British government and its handling of the competing claims of employers, workers and other interested groups has provided the main focus of debate on occupational health policy in recent years. Critical assessments of the Home Office include Geoffrey Tweedale and Philip Hansen's study of the asbestos regulations of 1931, and Sue Bowden and Tweedale's account of the attitude of civil servants to evidence of dangerous dust which caused byssinosis in the cotton textiles industry. ${ }^{6}$ Bartrip provides a more benign account of government action, arguing that three conditions were required before regulation could be approved: firstly, evidence of work hazard, secondly, available technology to ameliorate the hazard, and thirdly, an outcome which was not detrimental to the economic welfare of the industry and one which did not merely replace one hazard with other deleterious working conditions. ${ }^{7}$ Such debates are concerned with both the influence which different social actors exercised over the government and the degree to which the state, and more especially the élite group within the bureaucracy, responded to the evidence of dangers at the workplace.

There is little doubt that British employers resisted compensation reforms at key periods and sought to limit their liability for accident and injury claims, taking a critical perspective on information and initiatives demonstrating the hazards of their workplaces. They frequently attributed workers' illnesses to heredity, domestic or personal lifestyles, and infections or disabilities caused in the wider physical and social environment rather

\footnotetext{
${ }^{4}$ For examples of accounts sympathetic to workers, see Charles Levenstein and Gregory F DeLaurier with Mary Lee Dunn, The cotton dust papers: science, politics and power in the "discovery" of byssinosis in the U.S., Amityville, NY, Baywood Publishing, 2002; Alan Derickson, Black lung: anatomy of a public health disaster, Ithaca and London, Cornell University Press, 1998; Elaine Katz, The white death: silicosis on the Witwatersrand gold mines, Johannesburg, Witwatersrand University Press, 1994; Jock McCulloch, Asbestos blues: labour, capital, physicians and the state in South Africa, Oxford, James Currey, and Bloomington, Indiana University Press, 2002; Sue Bowden and Geoffrey Tweedale, 'Poisoned by the fluff: compensation and litigation for byssinosis in the Lancashire cotton industry', J. Law Soc., Dec. 2002, 29: 560-79; Sue Bowden and Geoffrey Tweedale, 'Mondays without dread: the trade union response to byssinosis in the Lancashire cotton industry in the twentieth century', Soc. Hist. Med., 2003, 16: 79-95; see Bartrip, Introduction to The way from dusty death (op. cit., note 2 above), for trenchant criticism of such historians in the asbestos story; and for the
}

disagreements between himself and others, see M Greenberg, and N Wikeley, 'Too little, too late? the Home Office and the Asbestos Industry Regulations, 1931: a reply', Med. Hist., 1999, 43: 508-10; P Bartrip, 'Rejoinder', Med. Hist., 1999, 43: 511-13.

${ }_{5} \mathrm{P}$ W J Bartrip, The Home Office and the dangerous trades: regulating occupational disease in Victorian and Edwardian Britain, Amsterdam and New York, Rodopi, 2002, pp. 29-35 and passim, for discussion of unions in relation to four main areas of occupational illness.

${ }^{6} \mathrm{G}$ Tweedale and $\mathrm{P}$ Hansen, 'Protecting the workers: the Medical Board and the asbestos industry, 1930s-1960s', Med. Hist., 1998, 42: 439-57;

Bowden and Tweedale, 'Poisoned by the fluff', op. cit., note 4 above.

${ }^{7}$ Bartrip, op. cit., note 5 above, p. 284. In contrast to some historians, our aim is to challenge the applicability of these conclusions by considering the complexities of the relationship between organized labour and the civil service in the regulation of dusty mines and in the compensation of those suffering from the effects of dust underground. 


\section{"A Mere Matter of Rock"}

than the conditions found in industry. ${ }^{8}$ Iron and steel firms challenged any suggestion that their foundries were the source of silicosis in the interwar period, just as coal masters argued that the hazards from dust underground were confined to the rock-cutting or "headings" work, and were not attributable to ordinary coal-getting operations or stone-dusting used to contain the risks of gas and firedamp exploding. The research of different historians also indicates that British civil servants were keen to accommodate the concerns of business about the impact of reform on the competitive performance of particular industries. ${ }^{9}$ The Home Office responded to the campaigns of pressure groups and the representations of organized interests by proposing what civil servants perceived as practical, consensual solutions which could attract the support of trade unions as well as business leaders. What is also apparent is the determination of the Home Office as well as British politicians in the interwar years that the state itself should not create or underwrite funds to compensate the victims of occupational illness or those injured and killed at work.

The mentality of policy-makers and regulators cannot be explained simply in terms of the rational model of action offered by Bartrip. Their attitudes reflected the established practices and the institutional structure of the British state in regard to compensation provision. From the time of the 1906 Workmen's Compensation Act, and when introducing national industrial schemes for silicosis sufferers after 1918, successive governments insisted that the risks and costs of occupational disease should be borne by the commerce that caused them. This assumed the legal capacity to identify and pursue an employer as well as a contract to insure present and future risks. Evidence from silicosis discussions indicates that the Home Office was careful to exclude any suggestion-from employers as well as unions - that the state would take responsibility for compensation insurance. Legal challenges as well as political lobbying compelled ministers and civil servants to review periodically the schemes designed to prevent respiratory diseases. The institutional structure and the bureaucratic culture of the Home Office in regard to the problem of injury and compensation, along with the adversarial legal system in which legal cases were determined, provided the setting within which the different groups sought to influence government policy in the early decades of the twentieth century.

The influence of distinct interests on the formation and implementation of industrial health policy in Britain has formed the first main thread of debate among historians. The second is concerned with the creation and status of knowledge about hazards at work. Bartrip offers both a rationalist and commonsense model of policy formation in which government officials require that the extent of hazard be scientifically verified and solutions are demonstrated to improve the overall safety of the workforce. Other scholars emphasize the degree to which understanding is shaped by social and political relationships. Allard Dembe has argued that the recognition of occupational disease and disorder has depended on three conditions: the selection of employees and working methods, the

\footnotetext{
${ }^{8}$ Bartrip argues that the extent of institutionalized conflict between workers and industrialists should not be exaggerated nor the benefits to workers and their families be underestimated. He calculates that by the end of the $1930 \mathrm{~s}$, between 5 and 6.5 per cent of the workforce in applicable industries were making successful claims for compensation. If dependents of
}

compensation recipients are included, this would imply that more than one million people were beneficiaries. P Bartrip, 'The rise and decline of workmen's compensation', in P Weindling (ed.), The social history of occupational health, London, Croom Helm, 1985, pp. 157-79, on pp. 164-5, 173-4.

${ }^{9}$ See work by P W J Bartrip and G Tweedale. 


\section{Mark W Bufton and Joseph Melling}

inclination of workers to seek medical treatment, and the agreement of physicians that there is a causal link between a medical condition and the work environment. ${ }^{10}$ These decisions have been made within a specific historical context. As David Rosner and Gerald Markowitz demonstrated in their pioneering study of silicosis regulation in the United States, popular and professional awareness of the disease was shaped by social, political and economic forces as well as technical and scientific ones. In these struggles the American labour unions played a key role. ${ }^{11}$

Historical research on the formation of occupational health policy, including compensation provision, and the discussions which decided the status of scientific knowledge regarding workplace hazards have largely concentrated on the activities of élite groups in contact with the Home Office. There has also been considerable sociological research on the subject of workers' responses to injury risks that emphasizes not only the capacity of employees to appreciate hazards, forming a "lay epidemiology", but also to decide on a civic or community strategy for dealing with the shared dangers of occupational illness. Michael Bloor has recently argued that the introduction of pneumoconiosis regulations in 1943 was the result of more than a decade of "political lobbying, legal arguments and epidemiological data gathering" by the South Wales Miners' Federation. The concern of the Welsh miners with pit safety arose, he suggests, not so much from civic engagement as from class struggle at work and the remarkably close connection between pit and community in South Wales. ${ }^{12}$ Such a perspective is valuable in refining our understanding of labour attitudes and registering the interplay between distinctive constituencies and national organizations in the political struggles over the regulation of workplace hazards. We would argue that the complex calculations and conflicts over injury at work are not easily reduced to an overriding narrative of class struggle and community solidarity. The policy preferences of a body such as the South Wales Miners' Federation were the outcome of a range of strategic calculations, timely manoeuvres and political accommodations inside and outside the union. There can be little doubt that the Federation played a pivotal role in guiding the claims of individual miners for compensation while pressing for the extension of the scheme to all underground workers. In promoting their members' claims, miners' unions made an important strategic decision to adopt the methodology of scientific proof and to agitate for incremental progress in compensation provision. This strategy did not inhibit the Federation from presenting a rising number of claims in the early 1930s and the early 1940s, even when half or more of them were rejected by the Silicosis Medical Board.

\footnotetext{
${ }^{10}$ Allard E Dembe, Occupation and disease: how social factors affect the conception of work-related disorders, New Haven, Yale University Press, 1996, pp. 3-6, 17-19, 229-32.

${ }^{11}$ David Rosner and Gerald Markowitz, Deadly dust: silicosis and the politics of occupational disease in twentieth-century America, Princeton University Press, 1991, pp. 4, 202-4. See also Gerald Markowitz and David Rosner, 'Corporate responsibility for toxins', The Annals of the American Academy of Political and Social Science, Nov. 2002, 584: 159-74. Seager has also showed how the political power of
}

American unions finally forced recognition of silicosis, D R Seager, 'Barre, Vermont granite workers and the struggle against silicosis, 1890-1960', Labor Hist., 2001, 42: 61-79.

${ }^{12}$ Michael Bloor, 'The South Wales Miners' Federation, miners' lung and the instrumental use of expertise, 1900-1950', Soc. Stud. Sci., 2000, 30, 1: 125-40; and idem, 'No longer dying for a living: collective responses to injury risks in South Wales Mining Communities, 1900-47', Sociology, 2002, 36, 1: 89-105, particularly pp. 100-102. 


\section{"A Mere Matter of Rock"}

We develop these arguments in the remainder of the article. The origins of the silicosis compensation schemes, their application to the coal mining industry and the pattern of claims from that sector are considered first. We then consider in more depth the contribution of the miners' unions to the reform process, with particular reference to the South Wales experience. The third section of the discussion examines the impact of the silicosis schemes on the pattern of compensation claims made by miners in the 1930s and the role of the unions in guiding their members through the assessment procedures laid out by government. Finally, we consider the appointment of a fresh investigation by the Medical Research Council (MRC) and the transformation of the medical diagnosis of respiratory diseases in coal miners during the early 1940s.

\section{The Origins of Silicosis Regulation and the Coal Mining Industry}

When the first significant legislation was introduced in 1919 to protect industrial workers from the dangers of silicosis, the mining of coal was not a serious target for regulation. Although the coal industry employed more than a million men before 1914 and was by far the largest form of mining undertaken in the United Kingdom during the nineteenth and early twentieth centuries, there was wide agreement that coal dust represented little direct threat to the respiratory health of those working underground. There had been considerable interest during the mid-nineteenth century in respiratory disease among coal workers. Lung disease was often identified by physicians as anthracosis or pneumoconiosis, although it was more commonly termed "miners phthisis" or "black lung" in Britain, the United States and other countries. By 1914 the lung disease of coal miners had largely disappeared from the purview of medical science. The reasons for its extinction were unclear even to those who pronounced its demise. ${ }^{13}$ One factor was the rise of silica as the archetypal "dangerous dust", a view which was still a medical orthodoxy in the early 1930s. ${ }^{14}$

The immediate concern of legislators and the Home Office in the early twentieth century was to control exposure to silica in such sectors as the mining of ganister, or fireclay, and

\footnotetext{
${ }^{13}$ Numerous authors have commented on this "collective forgetting" of the disease and its subsequent re-discovery. Posner wrote, "After this [the 1860 s] interest in anthracosis gradually faded out. The reason for this strange development ... is still a matter of controversy. The fact is that most leading figures in Occupational Medicine considered the chapter of the 'black lung' closed." E Posner, 'Milestones in the history of mineral dust pneumoconioses', in J Cule (ed.), Wales and medicine: an historical survey, London, British Society for the History of Medicine, 1975, p. 47. Posner cited no less an authority than Thomas Oliver and his edited collection Dangerous trades (1902) to support his view. Hunter cited the views of Edgar Collis in noting that, 'As the nineteenth century drew to its close doctors all over Great Britain had satisfied themselves that anthracosis of colliers had ... ceased to exist as a medical problem', Donald Hunter, The diseases of occupations, 6th ed., London, Hodder and
}

Stoughton, 1978, p. 1014. Collis had commented in 1915 that asthma among coal miners had been prevalent in South Wales but the disease had passed and that "conjecture as to its character and causation are idle". E L Collis, Industrial pneumoconioses with special reference to dust-phthisis, Milroy Lectures 1915, London, HMSO, 1915, p. 10. Derickson has described how Collis contributed to the medical rejection of the distinctive condition of pneumoconiosis by insisting that the symptoms were those of silicosis. Derickson, op. cit., note 4 above, pp. $48-50$.

${ }^{14} \mathrm{E}$ H Kettle, 'The relation of dust to infection', Presidential Address to Royal Society of Medicine, 1930, 25, pp. 1-16. "In different countries the composition of dust will vary, but all dangerous dusts have one factor in common: they all contain free silica, the dioxide of silicon; and so far as we know the degree of harmfulness of a dust depends upon the amount of free silica present in it." On p. 2. 


\section{Mark W Bufton and Joseph Melling}

other forms of "refractory" minerals that contained high levels of silica. This particular industry employed a few thousand miners, mainly in Yorkshire and parts of the Midlands. ${ }^{15}$ The Refractories Industries (Silicosis) Scheme introduced in 1919 was organized on the basis of compulsory industrial insurance, forming a compensation fund to which the employers contributed by a levy on the industry. The Scheme was regulated by the Home Office in consultation with Joint Committees made up of workers as well as employers' representatives. ${ }^{16}$ In the administration of this pioneer scheme there arose the familiar complaints from employers that respiratory disease, particularly tuberculosis, which originated beyond the workplace was presented as occupational silicosis. The situation was aggravated, they claimed, by the propensity of older workers to move into the refractories trades as unemployment forced them out of other industries during the early 1920s. ${ }^{17}$ At this stage the Home Office officials, Robert Bannatyne, Edward Middleton, Thomas Legge and Edwin Field, sought to reassure the employers who complained that "local authority" doctors who lacked specialist expertise were certifying tubercular workers as silicotic. ${ }^{18}$ After the passage of the important workmen's compensation legislation of 1923, the refractories employers argued that the government should bear part of the cost of a medical board rather than throwing the expense completely on the industry, which the Home Office officials again refused to entertain as "a departure from the policy as regards workmen's compensation generally". The civil servants similarly insisted that the medical board must be independent of the various parties who had an interest in the compensation award. ${ }^{19}$

From the early days of industrial silicosis schemes, employers in the more important industries were anxious to restrict the scope of Home Office regulation and to challenge the initiatives of medical researchers, who were perceived to be sympathetic to the interests of organized labour. The most powerful iron and steel firms challenged the extension in 1919 of the Refractories Scheme to iron foundries by an Order of the Home Secretary.

\footnotetext{
${ }^{15}$ PRO PIN 12/11, includes details of an investigation into ganister mining near Sheffield by E L Collis as Medical Inspector of Factories with marginal notes dated 25 April 1917 by R R Bannatyne of the Home Office. The same file has a 'Report on Proposed [Refractories] Scheme' by Dr A J Hall, Professor of Medicine at Sheffield University, 19 Dec. 1917. Both Thomas Legge and E L Collis commended Hall's work. Letters A J Hall to T Legge, 19 Dec. 1917, and E L Collis to Home Office, 18 Jan. 1918. Collis noted that Sheffield's ganister mines and metal grinding industry made it a centre of "industrial fibroid phthisis". The coal mining industry in Yorkshire was also affected.

${ }^{16}$ PRO PIN 12/14, 'Memorandum on Refractories Industries (Silicosis) Scheme', 4 Feb. 1919, indicates a levy on wages of 6.25 per cent on persons working about a mine or quarry where material worked contains 80 per cent or more silica. The limited demands on the Compensation Fund established led to a reduction in the levy to 5 per cent from 1 Jan. 1937 and further reductions were proposed in discussions on 4 April 1947. Government Actuary to Edwin Field at Ministry
}

of National Insurance, 21 May 1947. See also Arnold Wilson and Hermann Levy, Workmen's compensation. Volume 1: Social and political development, London and New York, Oxford University Press, 1939, pp. 264-6.

${ }^{17}$ PRO PIN 12/22, 'Notes of conference held at the Home Office 9 November 1922 regarding the

Refractories Industries (Silicosis) Scheme, 1919'.

Comments of Mr Davie for the Refractories

Industries Compensation Fund Ltd.

${ }^{18}$ Ibid. Bannatyne and his colleagues ruled out the appointment of a specialist Medical Officer to diagnose cases as impracticable and expensive, while also rejecting the suggestion that the Home Office could consider appeals against awards.

${ }^{19}$ PRO PIN 12/22, 'Notes of Conference with Refractories Industries Compensation Fund, 2 May 1924'. R R Bannatyne to Job Holland and to H J C Johnson. To the latter, Bannatyne noted: "Under our general compensation law the Certifying Surgeons and Medical Referees were appointed and controlled by the Home Office and he [Holland] thought the Medical Board must be independent of the parties." 


\section{"A Mere Matter of Rock"}

They argued that the trade unions would quickly demand the extension of any regulation covering workers involved in the crushing of ganister to all employees, even though "no enquiry has ever been made as to whether any risk does in fact exist in the foundries". ${ }^{20}$ The iron and steel masters clearly saw a direct relationship between the provision of compensation for silicosis and the continuing bargaining over wages and effort in the industry, where the presence of a possible risk placed a weapon in the hands of trade unionists to extract greater rewards as well as interrupt production on safety grounds.

There was a significant step towards the effective maintenance of silicotic workers with the introduction of the Workmen's Compensation (Silicosis) Act of 1924, a Medical Board of two medical officers examining claimants and granting certificates to workers under the different industrial schemes. The problem of deciding on the levels of risk posed by silica to the lungs of those working it was vividly revealed in discussions between the Home Office and employers engaged in the sandstone industry, following the introduction of a "Various Industries (Silicosis) Scheme" in 1928. In negotiations with Bannatyne and his Home Office colleagues at the end of the year, there was considerable discussion, and concern was expressed by both employers and unions regarding the proposal to base the definition of rock covered by the distinctive scheme as sandstone containing 50 per cent or more free silica. In these discussions it became apparent that the relationship between geological conditions and the onset of disease could not be precisely measured, Dr Edward Middleton acknowledging that the Home Office had no clear estimate of the amount of silica in rock strata which presented a hazard to workers. ${ }^{21}$ The exchanges also raised the threat to the workforce posed by tuberculosis, since the presence of silicosis-tuberculosis required the immediate suspension of the worker, whereas a diagnosis of "simple silicosis", or silicosis in its early stages, did not. The employers and unions agreed that employees should be compelled to attend a medical examination within two months of being hired. ${ }^{22}$

The question of the diagnosis of silicosis and the experience of administering the Refractories Industries Scheme were considered by a Departmental Committee of the Home Office appointed in early December 1928 and reporting in June 1929. Acknowledging the difficulty of diagnosing silicosis and distinguishing its symptoms from other chest diseases (including tuberculosis), as well as the impact of coal dust on silicotic lungs, the Committee expressed itself convinced that "silicosis is more widespread than is generally believed, and that it occurs to some extent in a number of industries and

\footnotetext{
${ }^{20}$ PRO PIN 12/12, 'Silicosis Order: Minutes of Deputation from the Iron \& Steel Manufacturers [to Home Office], July 25 1919'. Opening statement by J E Baker, Chairman of the Sheffield Engineering Employers' Association. The regulations covered materials and articles which contained 80 per cent silica. Baker noted that the Order had been based on a report by Sydney Smith and Dr E L Collis on the mining of silica and making of silica bricks rather than foundry work.

${ }^{21}$ PRO PIN 12/39, 'Sandstone Industry (Silicosis) Scheme: Notes of Conference with representatives
}

of employers and workers, at the Home Office, December 19 1928', pp. 11-12, Edward Middleton to Hudson Brook. Bannatyne later commented: "I do not like to exclude anything where there is any risk." Ibid., p. 25. PRO PIN 12/39, "Note of further conference with employers and workers in regard to definition of "sandstone", 20 Dec. 1928.

${ }^{22}$ PRO PIN 12/39, Ibid., pp. 40-1: R R Bannatyne to $\mathrm{H}$ Brook, and Davie to Hilton. It was also agreed that workmen must reveal their previous employment history, at the risk of being denied compensation, subject to Joint Committee decision. Ibid., p. 46. 


\section{Mark W Bufton and Joseph Melling}

occupations where its presence has not been suspected." ${ }^{23}$ The Committee recommended the extension of the Medical Board model developed in the refractories and sandstone industries for fresh schemes in potteries, with the Sheffield Board becoming the central bureau under a chief Medical Officer for the training of full-time specialists to staff the Boards. The Committee also suggested closer links with the Tuberculosis Service for the organization of the radiological and radioscopic examinations that played an essential part in the diagnosis of silicosis. ${ }^{24}$ The discussions of the various schemes during and after 1919 indicate that by the time the coal mining industry was brought under Workmen's Compensation rules by the Various Industries (Silicosis) Scheme of 1928, a number of contentious issues regarding silica hazards and the examination of workers had already been aired at the Home Office.

The first permanent Medical Inspector of Mines, Dr S W Fisher, was appointed at the end of 1927, some three decades after medical experts were appointed to the élite corps within the Factory Department at the Home Office. ${ }^{25}$ Fisher quickly became a significant figure in discussions about silicosis in coal mines. He assisted the Home Office Committee which reviewed the arrangements for the diagnosis of silicosis in 1929, became a member of the Industrial Pulmonary Diseases Committee (IPDC) of the Medical Research Council, and gave evidence to the Royal Commission on Safety in Coal Mines in 1936. Fisher commented on the investigations of the IPDC when giving his evidence to the Royal Commission, though his most telling comments related to the evidence of serious respiratory disease in miners who had never worked in silica-rich rock such as hard headings, particularly in the South Wales coalfield. ${ }^{26}$ Fisher's account reflected the confusion among medical and mining researchers and the absence of any consensus on the nature and causes of chest diseases among colliers in the anthracite and other coalfields. ${ }^{27}$ The bewildering array of evidence and theories concerning the lung disorders among different groups of miners provided the impetus for the attempts of various researchers to undertake a fresh investigation that led to the ovular study by the Medical Research Council, which we discuss below.

Although the scientific and medical evidence on silicosis and pneumoconiosis did not provide any clear explanation of the extent of lung diseases among coal miners in the 1930s, there were important changes (particularly in 1931 and 1934) in the requirements of the compensation schemes available to miners. These relaxed some of the eligibility requirements for those wishing to claim compensation and extended the provisions to allow more miners to submit claims after the Various Industries Scheme first came into force at the beginning of 1929. The revisions in the scheme were accompanied by

\footnotetext{
${ }^{23}$ PRO T161/806, 'Silicosis (Medical Arrangements) Committee, Report of the Departmental Committee appointed by the Secretary of State to advise as to the medical arrangements which could be made for the diagnosis of Silicosis', pp. 7-8.

${ }^{24}$ Ibid., paras. $7-10$, pp. $12-15$. The report concluded with an appeal for further research on the subject of silicosis.

25 'Minutes of Evidence taken before the Royal Commission on Safety in Coal Mines, Evidence submitted by Dr S W Fisher, 2 November 1936',
}

[hereafter, Fisher evidence to RCSCM] p. 843. Copy in PRO POWE 8/199. Fisher emphasized investigations of the lungs of rock drillers from the Somerset coalfield in 1925-31.

${ }^{26}$ Fisher evidence to RCSCM, Minutes of Evidence, paras. 22323-22332.

${ }^{27}$ Mark Bufton and Joseph Melling, 'Coming up for air: the role of experts, employers and trade unions in compensation schemes for silicosis sufferers in the United Kingdom, c. 1922-1934', Soc. Hist. Med., 2005, 18(1): 1-24. 


\section{"A Mere Matter of Rock"}

noticeable increases in the number of compensation applications submitted, accepted and rejected in the early 1930s. These reforms cannot easily be attributed to any fresh scientific enquiry or to the independent initiatives of civil servants at the Home Office. The impetus to early changes in the Various Industries Scheme as it affected the coalmining industry came, in part at least, from the campaigns of miners' unions to improve compensation provision for those suffering from dust-related illnesses. The next part of the article considers the particular contribution of the South Wales Miners' Federation to the compensation debate at this period.

\section{The Miners' Unions and the Silicosis Compensation "Crisis"}

The Miners' Federation of South Wales was an amalgam of district unions and lodges or branches, which organized colliers across the region, as well as having close contacts with miners in Somerset. The western area of South Wales around Swansea was the district where the anthracite coal seams were concentrated. Anthracite was a hard coal with high calorific value, particularly valuable for industrial and transport uses, though it was in these mines that the highest incidence of lung diseases among coal miners were recorded. The Federation first became actively involved in the question of compensation for silicosis sufferers in 1926-27, when W H Mainwaring from South Wales raised the matter at the Miners' Federation of Great Britain (MFGB) 1927 conference. $^{28}$ In 1926, the year of the General Strike, it was reported to the South Wales Federation that the MFGB had met with the Conservative Home Secretary to discuss the inclusion of silicosis as a scheduled disease for the purposes of the Workmen's Compensation legislation. ${ }^{29}$

There was limited success with the inclusion of coal mining in the 1928 Various Industries provisions, though the evidence we have from other areas of Wales is that very few cases of silicosis were recorded for compensation purposes before $1928 .{ }^{30} \mathrm{~A}$ key provision of the 1928 Scheme was that any claimant for compensation had to prove that he was working in rock that contained at least 50 per cent free silica and had been working in the industry for a considerable number of years. By 1930 the Federation had established its own Silicosis Committee, pressing for amendments to the Silicosis Order made by the Home Office. The Federation also demanded that the 50 per cent rule be dropped from the Various Industries regulations for the industry. ${ }^{31} \mathrm{We}$ can trace a contrast between the views expressed by the members of the Trades Union Congress General Council, and even the MFGB, and those recorded by the Federation at this period. After the introduction of new regulations for workers engaged in trades affected by silicosis and asbestosis in 1931, the

\footnotetext{
${ }^{28}$ MFGB, Annual Conference, 25 July 1927, Proceedings, p. 73. Mainwaring stated that the South Wales district was not severely affected by silicosis but might soon be because of the nature of the work undertaken in coalmining.

${ }^{29}$ SWMF, Minutes of Council Meetings, Annual and Special Conferences 1926, Council Meeting, Miners' Office, Cardiff, 6 Feb. 1926.

${ }^{30}$ Joseph Melling, 'The risks of working and the risks of not working: trade unions,
}

employers and responses to the risk of occupational illness in British industry, c. 1890-1940s', London, ESRC Centre for the Analysis of Risk and Regulation at the London School of Economics and Political Science, Discussion Paper no. 12, includes figures from North Wales Mutual.

${ }^{31}$ SWMF, Minutes 1930, Silicosis Committee, 6 Feb. 1930; SWMF, Minutes, Cardiff, 27-28 June 1930. 


\section{Mark W Bufton and Joseph Melling}

TUC expressed a debt of gratitude to the Labour Home Secretary who secured the passage of the new measure, which they considered a "godsend". The MFGB conference of 1931 also heard the TUC commending the reduction in silica levels from the 80 per cent specified in an original 1918 scheme to the 50 per cent required under the 1928 provisions, while acknowledging that this remained unfair to many workers. ${ }^{32}$

The MFGB had pressed their own arguments on the Home Office, stating that the 50 per cent rule rendered the scheme "almost worthless to coalminers" and that almost all operations within the coal mine should be eligible for compensation if a worker was found to be suffering from silicosis. At this point, the Home Office was drafting amendments to the 1928 Various Industries Scheme, removing the requirement on the employee to demonstrate that he had worked in rock which contained at least 50 per cent free silica. The MFGB also urged that the provision that a mine worker should have been employed for at least three years before becoming eligible for compensation should be removed, and those miners who were already suffering from the disease should be given compensation. Faced with vigorous opposition from the Mining Association of Great Britain, the Home Office firmly rejected these proposals. The MFGB Silicosis Sub-Committee complained that the schemes were still "enumerating processes" rather than scheduling the coal mining industry as a single process, though the MFGB decided that it would be "dangerous to insist further on [its] own amendments". ${ }^{33}$ The MFGB had been concerned that the Medical Board appointed under the Scheme could still take into account the length of time a worker had been employed in the industry before awarding compensation, though they agreed to accept the revisions. ${ }^{34}$

The improvements secured in 1930-31 did not impress the deputation from the Federation, including Mainwaring and Evan Williams, who travelled to the Home Office in 1932 to discuss the administration of the Various Industries Scheme. The Welsh Federation representatives clearly felt that the leadership of the British Miners' Federation, led by A J Cook, had displayed a limited understanding of silicosis and the compensation problems faced by the miners in areas such as South Wales. ${ }^{35}$ One difficulty with the 1929 Scheme was the ruling that no silicotic miner could be considered eligible for compensation unless he had worked in areas where the free silica content of rock was at least 50 per cent. The Federation complained at the British Federation conference that they employed chemists at a rate of $£ 30$ per analysis to demonstrate that the rock had sufficient silica to comply. Representatives of the Somerset miners (who were exposed to high levels of silica) also complained that they found it difficult to secure medical support for a compensation application, even when high levels of silica were undoubtedly present. Geologists as well as chemists were consulted as miners and their unions sought expert testimony in support of silicosis claims. ${ }^{36}$

\footnotetext{
${ }^{32}$ MFGB, Annual Conference, 1931, pp. 83-6.

${ }^{33}$ MFGB, Report of the Executive Committee, June 1931, pp. 157-60. The MFGB saw the main advantage of the 1930 Various Industries (Silicosis) Amendment Scheme lay in the removal of the obligation on the miner to prove the composition of the siliceous rock.

${ }^{34}$ MFGB, Minutes of the Executive Committee, 12 Feb., 1931, pp. 2-4, for concerns of the Sub-Committee.
} 


\section{"A Mere Matter of Rock"}

Having accumulated the opinion of geologists as well as the details of seventy miners unable to secure compensation, the MFGB had a meeting with the Home Office in 1933 to discuss the "public scandal" of compensation in the coal mining industry. The MFGB deputation included D F Davies of the Anthracite Miners Association in South Wales, who argued that geological investigation clearly indicated that miners could contract silicosis without working in rock that possessed a high composition of silica. The Home Office insisted that its own medical experts considered that all hazardous occupations in coal mining were covered by the 1931 provisions. Rather than geological evidence, Bannatyne and his colleagues in Whitehall emphasized that individual medical histories of men who had contracted silicosis without compensation were critical to pressing the case for the modification of existing schemes. As well as the medical diagnosis of silicosis, the industrial biography of an individual miner's career became a vital feature of the compensation debate. In this context, the MFGB dispatched details of fifty-nine cases of miners certified by the Medical Board as silicotic who were refused compensation in court because the men could not prove they had worked on scheduled rocks. The Federation insisted that such cases demonstrated the urgent need for the Home Secretary to issue an Order extending compensation rights to all underground workers. ${ }^{37}$

There were also complaints of delays in issuing new regulations for silicosis sufferers who were not compensated. ${ }^{38}$ Among the most prominent critics of the 1931 Scheme and advocates of radical reform had been unionists from Somerset and South Wales. James Griffiths of Somerset told the MFGB's conference in summer 1934 that the need to prove the silica content of the rock in which they worked, particularly where employers hired geologists to argue that the sediments contained little or no hazardous silica, forced the unions into expensive legal battles to prove that the rock was indeed sandstone. The unions were concerned with prevention as well as compensation, with early diagnosis enabling their members to "get out of the pit and so protect their health and lives". ${ }^{39}$ Griffiths shared the radical view held in South Wales that any miner diagnosed by the Medical Board as a silicosis sufferer should be compensated without further ado, since the disease was far too serious for its compensation to depend on "a mere matter of rock". In support of this argument he cited the controversy over the cases of twenty-three men at the Tirbach Colliery in Ystalyfera. These miners had been diagnosed in 1932-33 as suffering from silicosis but only two had secured compensation awards, scientific witnesses for the colliery having argued that employment in Tirbach was not responsible for the men's condition. At the Federation meeting of the British mining unions, Griffiths denounced the "scandal" where the employers' Mining Association was able to devote its considerable resources to "buying brains and experts in order to confuse counsel and the government". ${ }^{40}$ Faced with such expert testimony in the court room, the MFGB decided to employ the geologist A Herbert Cox to prepare a detailed report in support of the cases

\footnotetext{
${ }^{37}$ MFGB, Minutes of Executive Committee, 26-27 Oct., 1933, pp. 14-16, and 23 Nov. 1933, p. 3. In this account of the meeting at the Home Office, the official Fudge acknowledged that medical experts differed on how the disease was contracted and that it was essential that a man's working career was known.
}

\footnotetext{
${ }^{38}$ MFGB, Minutes of Executive Committee Meeting, 17 May 1934, p. 4.

${ }^{39}$ MFGB, Annual Conference, 16-18 July 1934, Tuesday's Proceedings, p. 36.

${ }^{40}$ Ibid., MFGB, Annual Conference, 16-18 July 1934, Tuesday's Proceedings, pp. 36-7.
} 


\section{Mark W Bufton and Joseph Melling}

prepared by the South Wales union. Cox found that "shales" contained the silica mineral in "combined form" and argued that the exact percentage of silica which could damage the lungs of miners working in dry and dusty conditions was unknown. After dispatching Cox's report to the Home Office, the Federation journeyed to London to discuss the question further, whereupon the civil servants again stressed the value of individual cases and employment records of miners who were suffering from serious lung disease without being certified as silicotic. ${ }^{41}$ In these and other ways the activities of the South Wales Federation contributed directly to the debate on the reform of the Various Industries Scheme in 1934.

British miners' leaders could reasonably argue at the end of 1934 that the amendment of the Various Industries Scheme was the fruit of the "enormous amount of money expended and great effort exercised by the Federation in prosecuting claims, and making representations to the government for improved legislation". ${ }^{42}$ The 1934 Scheme extended the compensation provisions to all underground workers, though the new provisions applied only to workers employed after 22 October 1934 without any scope for retrospective awards. The reform did not resolve the contentious question of silica content in rock. Bannatyne assured the unions that the Home Secretary believed the provisions now covered any colliery worker employed underground, though the interpretation of the rules was clearly a matter for judges rather than politicians. ${ }^{43}$

The battle duly moved to the courts in 1935-36, with the Welsh Federation again assuming a prominent role in the struggle with mine owners and insurers, and declaring that the issue had "developed into a form of intense struggle between ourselves and the Employers". This struggle was most apparent in legal cases such as those involving the claim of the Tirbach miners which involved the employment of geologists as well as solicitors and medical specialists. ${ }^{44}$ Although the 1934 scheme held out the prospect of compensation to all underground coal miners who were certified as silicotic, the employers challenged the decision in the important case of Wragg v. Fox, arguing before the High Court that the 1934 Amendments were ultra vires. ${ }^{45}$ As a consequence, the progress of individual compensation claims was blocked until the matter was resolved. ${ }^{46}$ After the Court of Appeal ruled in favour of the employers in 1935, the Federation determined to "fight the issue to the end". In practical terms this meant a shift back to lobbying the Home Office in favour of another Order to fulfil the declared intentions of the 1934

\footnotetext{
${ }^{41}$ MFGB, Annual Conference, 16-18 July 1934, pp. 37-8.

${ }^{42}$ SWMF, Minutes of Council Meetings, Annual and Special Conferences 1935, Report of Executive Council, 1934-1935, Cardiff, pp. 19, 24-5.

${ }^{43}$ MFGB, Minutes of Executive Committee Meeting, 22 Nov. 1934, pp. 1-2.

${ }^{44}$ SWMF, Minutes of Council Meetings, Annual and Special Conferences 1936, Report of Executive Council, 1935-1936, Cardiff, pp. 35-7.

${ }^{45}$ The legal point at issue according to the union was whether paragraph 2 of the Various Industries (Silicosis) Scheme 1931, applied to the new Various
}

Industries (Silicosis) Scheme of 1934. The original paragraph read: "Provided that the employer shall not be liable under this paragraph in any case where he proves to the satisfaction of the County Court judge or other arbitrator that the workman has not, during the employment to which the disease is alleged to be due, been exposed to the dust of silica rock". Also Butterworths' Workmen's Compensation Cases, 1935, 28 (new series): 447-68.

${ }^{46}$ SWCC: MNA/NUM/3/5/box G.17 1937, Compensation Correspondence Area No. 6, letter to Oliver Harris, General Secretary, SWMF, area no. 6, from Terence Wall, 21 May 1937. 


\section{"A Mere Matter of Rock"}

amendments. ${ }^{47}$ The matter was ultimately decided in the House of Lords as the MFGB finally claimed victory in the Wragg case during $1937 .{ }^{48}$

The activities of the miners' organizations clearly influenced the progressive revision of different silicosis schemes introduced from 1928, though union activity was largely devoted to fighting individual cases of silicotic miners rather than engaging in a generalized public campaign in favour of comprehensive legislation. The lobbying of civil servants as well as parliamentarians was a significant feature of union activities during the 1930s, though it would be misleading to exaggerate the importance of these London meetings. The campaign for more liberal silicosis provisions is more accurately understood as a cumulative movement which extended from the court cases pursued by miners and their supporters in a range of districts, including even areas of west Scotland, which were little known for vigorous unionism during the early twentieth century. ${ }^{49}$ These district unions and even the national Federation of miners in Britain faced considerable difficulties in seeking to deploy expert testimony to balance that of the eminent consultants whom the employers' legal advisers could secure. ${ }^{50}$ The experience of the Wragg and other legal contests persuaded the miners' leaders of the importance of achieving a clear diagnosis even after the rules for compensation were extended in the 1934 revisions.

The next section briefly considers the impact of these compensation schemes on the pattern of claims that represented the attempts of diseased or deceased miners and their dependents to secure financial support from the owners.

\section{The Compensation Claims of Miners in the 1930s}

The impact of revisions in government regulations on the attitudes of miners towards compensation for industrial disease is difficult to ascertain with any precision. We have reliable information only on the claims actually made. The figures which survive for silicosis and pneumoconiosis claims indicate a rising trend from 1931 (Figure 1). The number of applications and certificates granted for the South Wales coalfield appear to have risen steadily in the 1930s and again, but more sharply, in the early 1940s.

There are various ways in which the rising trend in applications and certificates granted in South Wales may be explained. Sir Andrew Bryan, a former Chief Inspector of Mines and Quarries, suggested that increased mechanization and the drive to higher output produced a heavier concentration of dust, contributing to a worsening of respiratory

\footnotetext{
${ }^{47}$ SWMF, Minutes of Council Meetings, Annual and Special Conferences 1937, Report of Executive Council, 1936-1937, Cardiff, pp. 40-1.

${ }^{48}$ Butterworths' Workmen's Compensation Cases, 1937, 30 (new series): 51-63. SWMF, Minutes of Council Meetings, Annual and Special Conferences 1938, Annual Report of Executive Council, 19371938, Cardiff, pp. 41-2. MFGB, Minutes of Executive Committee Meeting, 24 Mar., 1937, p. 76. The phrase about legal victory in Wragg v. Fox belonged to Ebby Edwards, Secretary of the MFGB.

${ }^{49}$ University of Glasgow Archives, UGD 162, Ayrshire Mutual Insurance Association: Minutes,
}

1 Sept. 1933, 1 June 1935, for individual cases. In late 1934 the Ayrshire Association discussed the work of the Silicosis Committee in London and the Home Secretary's decision to include all underground workers in the Various Industries (Silicosis) Scheme, without agreeing to the insertion of an order "that it would only apply to men who were employed on \& after the date of the order". Minutes,

11 Dec. 1934, concerning meeting of 17 Oct. 1934.

${ }^{50}$ MFGB, Minutes of Executive Committee Meeting, 16 Aug., 1934, pp. 2-5. 


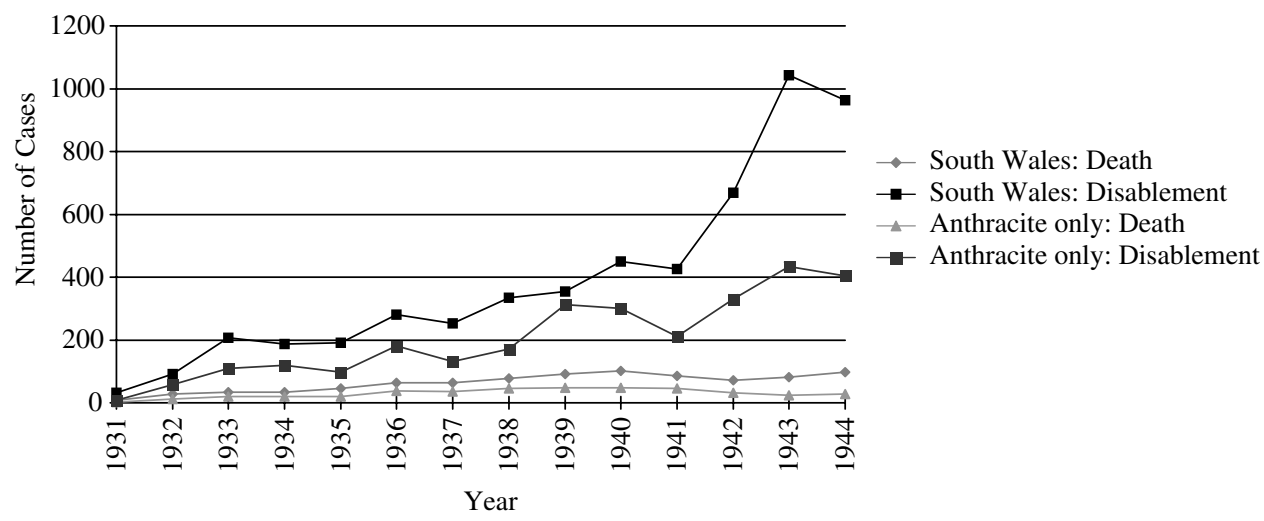

Figure 1: Silicosis and pneumoconiosis compensation awards to South Wales miners.

Note: The above figures do not include the Forest of Dean area for the years 1937-1939. The figures probably understate the incidence for 1944 since there was a considerable accumulation of cases where miners were awaiting examination, only to be considered in 1945.

Source: SWCC: MNC/PP/35/1 'National Union of Mineworkers (South Wales Area Council) Reports on the incidence of the diseases silicosis and pneumoconiosis, and the preventative measures adopted to combat the diseases in South Wales', 22 August 1945.

disorders and rising claims. Such arguments have to be treated with some scepticism since in the South Wales mines there was limited progress of mechanical cutting. Both geology and the traditional working methods of the region provided obstacles which were significant enough to inhibit even the progressive Powell Duffryn company from fully mechanizing their coal faces. Only 7 per cent of South Wales coal was mechanically cut in 1927 and by 1939, it had risen to only 16 per cent. Even after the drive for maximum output during the war years, machines were cutting less than a third of the area's coal in 1944. Historians of the industry agree that the most important form of mechanization seen in South Wales lay in the rapid introduction of machine conveyors, the proportion of coal being carried mechanically rising from just over a quarter in 1928 to almost half by 1939. The evidence suggests that the face cutters were not the main force behind the rise in compensation claims even if they undoubtedly led to an increase in underground dust where they were deployed. ${ }^{51}$

There may be greater reason to accept Bryan's claim that there was a drive for increased output, or at least that employers were able to increase miners' workloads by taking advantage of depressed economic conditions and high unemployment to shift the "effort

\footnotetext{
${ }^{51}$ The friable nature of the South Wales coal restricted the use of machines for under-cutting seams. Barry Supple, The history of the British coal industry: vol. 4: 1913-1946: the political economy of decline, New York, Clarendon Press, 1987, pp. 31, 316-17, 384; David Greasley, 'The diffusion of machine cutting in the British coal industry, 1902-38',
}

Explorations in Economic History, 1982, 19: 246-68, on pp. 247, 253; idem, 'Fifty years of coal-mining productivity: the record of the British coal industry before 1939', J. Econ. Hist., 1990, 50: 877-902, on p. 883; T Boyns, 'Jigging and shaking: technical choice in the South Wales Coal industry between the wars', Welsh Hist. Rev., 1994, 17: 230-51. 


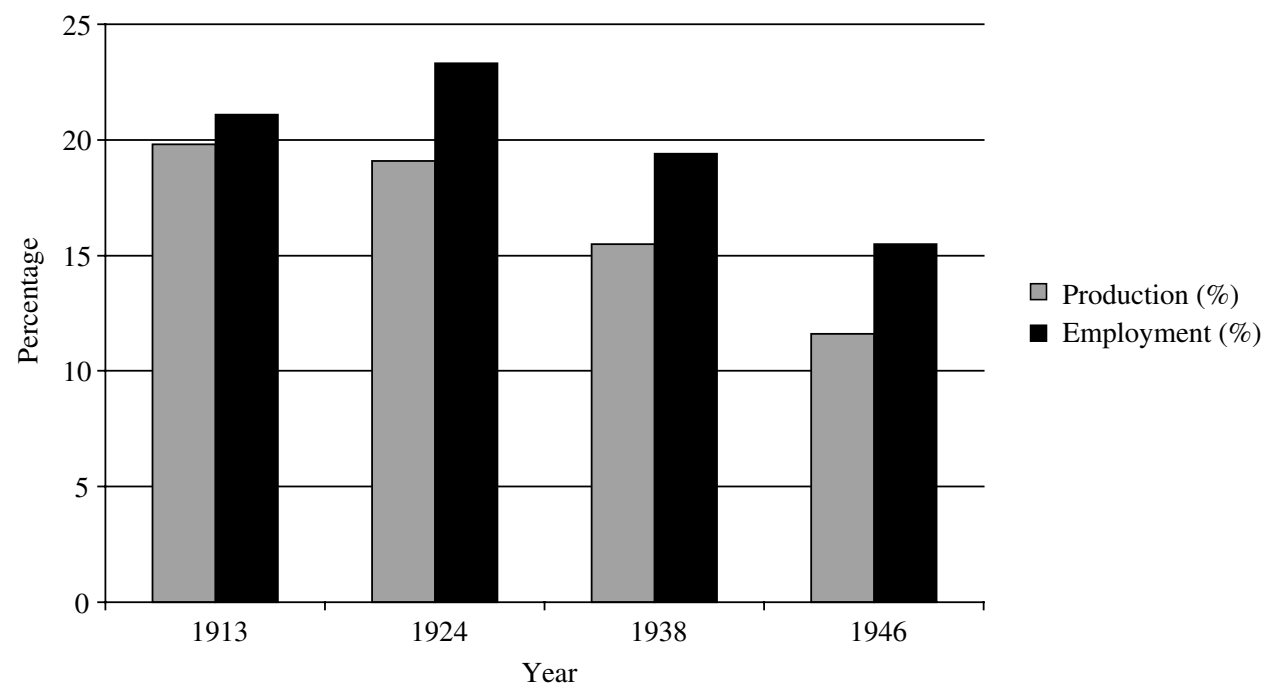

Figure 2: Output and employment in deep mined coal in South Wales, 1913-1946.

Note: The other regions are Scotland, Northern, North-West, Yorkshire, East Midlands, West Midlands, which make 100 per cent.

Source: B Supple, The history of the British coal industry, vol. 4, New York, Oxford University Press, 1987, p. 21.

bargain" in favour of colliery firms. ${ }^{52}$ The efforts by coal owners to use their over-men to drive output in these years could have provoked miners, including elderly underground workers, to present themselves for examination and pursue compensation in a bid to leave the industry and secure some form of maintenance. In the absence of detailed information on the age and output of the workforce, wage incentives and working practices, it is virtually impossible to address this question. The general figures which we do possess on production and employment in the South Wales coalfield (indicated in Figure 2) suggest that both were declining in almost equal proportions after 1924, which does not necessarily suggest a shift in individual output or a decisive move of the effort bargain in favour of the coal masters.

Further clues to the pattern of illness and compensation applications may be found in the growing number of claims that were refused in the late 1930s. The available data for 19391943 reveals a marked rise in refusals (Table 1$).{ }^{53}$

\footnotetext{
${ }^{52}$ The effort bargain is the relationship between work effort and reward (pay), more effort for less reward means a shift in power and control to the employers and less work for the same or more reward means a shift in power and control to the workers. The locus classicus on this is William Baldamus, Efficiency and effort: an analysis of industrial administration, London, Tavistock, 1961; for the larger context of workplace supervision and the effort bargain, see Joseph Melling, 'Safety, supervision and the pursuit of
}

productivity in the British coal mining industry, 1900-1960', in J Melling and A McKinlay (eds), Management, labour and industrial politics in modern Europe: the quest for productivity growth during the twentieth century, Cheltenham, Elgar, 1996, pp. 145-73.

${ }^{53}$ It would appear that since 1931 refusals for certificates had stood consistently around 50 per cent of all claims. PRO FD1/2898, Letter to Dr Faulkner, MRC, from Ministry of Fuel and Power, 16 Jan. 1947. 


\section{Mark W Bufton and Joseph Melling}

Table 1

Number of coal miners' patient cases certified and rejected by the Medical Board (Silicosis) in the South Wales Coalfield, 1939-1943

\begin{tabular}{lrrrrr}
\hline Year & 1939 & 1940 & 1941 & 1942 & 1943 \\
\hline Certificates issued (partial or total disablement) & 387 & 428 & 474 & 735 & $985^{*}$ \\
Certificates refused & 271 & 394 & 662 & 957 & $963^{*}$ \\
Total & 658 & 822 & 1136 & 1692 & 1948 \\
Certificates refused (percentage of total) & 41 & 48 & 58 & 56.5 & 49
\end{tabular}

*Of these 399 certificates were issued and 264 certificates refused under the new scheme, which came into operation on the 1 July 1943.

Sources: PRO POWE 8/266, 'Ministry of Fuel and Power, report of the Advisory Committee on the Treatment and Rehabilitation of Miners suffering from Pneumokoniosis', draft, p. 6.

There has been little systematic investigation of the increase in claims. Philip D'Arcy Hart, who was closely involved in research on pneumoconiosis in the 1940s, has suggested that the 1934 Scheme secured compensation on the granting of a certificate by the Medical Board and that this led to a dramatic rise in the number of claims. Refusals also increased as X-ray and post-mortem examinations failed to discover the classical or "ordinary" symptoms of silicosis. The result was growing discontent on the South Wales coalfield. ${ }^{54}$

D'Arcy Hart provides a plausible explanation, but closer analysis of the evidence reveals variations both in applications and in the proportion of certificates which were refused, long after the 1934 changes in eligibility rules. Further clues are suggested in David Michaels' argument that a liberalization of injury benefits may cause an "instant prevalence bias", as employees are given greater incentive to report illnesses or discomforts that were previously tolerated. ${ }^{55}$ In this context it is worth recalling, however, that the relaxation of the qualifying rules did not relate directly to medical symptoms, but rather to tenure in the industry and to the known existence of silica-rich rock in the proximity of the claimant's workplace. The rising number of applications has to be understood, in part at least, in terms of the procedures for examination and the patient-physician relationship which Dembe and others have emphasized. There is some evidence that medical practitioners in South Wales were more inclined to diagnose patients with chest illness as potentially silicotic, as compared with physicians in other districts associated with silicosis. One union official complained to an MFGB conference in 1934 that Somerset doctors were diagnosing silicosis as bronchitis and that only when these patient cases were considered by specialists at the Medical Board were they identified as silicotics. ${ }^{56}$ One factor in the

\footnotetext{
${ }^{54} \mathrm{P}$ D'Arcy Hart, 'Chronic pulmonary disease in South Wales coal mines: an eye-witness account of the MRC Surveys (1937-1942)', Soc. Hist. Med., 1998, 11: 459-68, on p. 462.

${ }^{55}$ Dembe, op. cit., note 10 above, p. 92 . Dorman similarly notes, "when benefits rise and claims follow suit, it may well be that fewer legitimate claims are being suppressed". Peter Dorman, Markets and
}

\footnotetext{
mortality: economics, dangerous work, and the value of human life, Cambridge University Press, 1996, pp. 198-9. It is remains methodologically difficult to estimate whether there is any "demonstration effect", implicit in the reduced suppression hypothesis, from available figures.

${ }^{56}$ MFGB, Annual Conference, 16-18 July 1934, Tuesday's Proceedings, p. 36.
} 


\section{"A Mere Matter of Rock"}

willingness of Welsh doctors to offer a diagnosis of silicosis was the frustration felt by many physicians at the controversy and uncertainty which had arisen over the aetiology of silicosis. ${ }^{57}$ Another was the concern that the issue of compensation or "pensionability" of miners only compounded these difficulties by requiring a degree of certainty which medical science could not provide. As Dr Matthews of Neath commented with some exasperation:

We do not know exactly how much whisky is required to produce cirrhosis of the liver ... Health and disease are relative conditions. But the standards imposed upon the diagnosis of pensionable dust disease almost preclude the diagnosis being made at all by the doctors most concerned.

If a person is severely ill or dying with a disease commonly believed to be caused by dust, rarely, if ever, seen under conditions not associated with dust, and presenting the typical clinical features ... medical diagnosis should not be hampered by the question of its pensionability, and, whether the conditions be silicosis, anthracosis, silico-anthracosis or tubercle silico-anthracosis, provision should be made for them. ${ }^{58}$

The propensity of such doctors to provide an initial diagnosis of silicosis was also undoubtedly influenced by the readiness of the Federation and its lodges to use the services of physicians who were known to be sympathetic to the predicament of miners with chest problems.

The Federation appointed its own compensation secretary and the officials of the local lodges appear to have played a vital role in advancing many, possibly most, silicosis injury claims. When Jacob H of Abergorky Lodge died in 1938, for example, the Federation's Area Secretary contacted Alderman Rhys Evans for assistance in presenting a compensation application to the Medical Silicosis Board in view of the owners' request for a post-mortem. ${ }^{59}$ In other instances individual miners appear to have used the prospect of compensation (including where symptoms of miners' nystagmus as well as respiratory problems were evident) to bargain with the company about the offer of employment rather than pressing an injury claim, frequently compromising any subsequent claim for compensation via the union. In July 1936 United National Collieries wrote to the Federation's Porth secretary regarding the claims of two injured miners, stating that on the closure of Abergorky Colliery their mine manager had met the men concerned and they had "definitely said that if they could get work they would not bother about compensation. He provided them with work on this condition." 60 The evidence is scanty and fragmentary, although it appears that the Federation perceived their role as the protector of dependents as well as injured miners, advising family

\footnotetext{
${ }^{57}$ Bufton and Melling, op. cit., note 27 above, provides a discussion.

${ }^{58}$ National Library of Scotland, J S Haldane Papers, 10306, Box of unlisted materials:

Dr Matthews, 'Silicosis and other dust diseases: Neath Area'. Also in this collection is a paper by Dr Williams of Swansea, 'Pneumonoconiosis in coal hewers', which shows 11 of 39 coal hewers with chest symptoms (chiefly anthracite workers) showed infective silicosis from x-ray films, 21 being non-infective.
}

\footnotetext{
${ }^{59}$ SWCC: MNA/NUM/L/3/18, Abergorky Lodge Compensation Cases and correspondence: case of Jacob H deceased. Tal Thomas to Rhys Evans, 14 Dec. 1938, 30 Dec. 1938, 10 Jan. 1939.

${ }^{60}$ Ibid., case of G P J, regarding nystagmus, 23 May 1933, and letter of W J Thomas to David Lewis, 7 July 1936. Further correspondence 28 July-31 Aug. 1936 suggested that T John had been paid compensation while G P J was "in regular employment". The latter possibly referred to regular employment disqualifying G J P for partial disability payment.
} 


\section{Mark W Bufton and Joseph Melling}

members on negotiations with insurance firms as well as preparing an application for compensation. $^{61}$

The limited correspondence and documentation which survives for individual claims in these years provides us with some understanding of the choices available to miners who displayed some symptoms of silicosis. Individuals were capable of conducting their own negotiations in regard to employment, presumably calculating the costs and benefits of an application where the likeliest outcome was either a decision by the Medical Board that silicosis was not present or the removal of the applicant from arduous underground labour to light or moderately heavy work. In the decision to apply for compensation under the schemes of 1931-34, the miners' relationship with their physicians figured, as well as the crusade of the miners' unions to promote the rights of members and dependents. The unions appear to have been principally concerned to remove or reduce the responsibility on the miner to demonstrate a specific period of employment and proximity to hard silica-laden rock. They argued that the relevant condition was the lung disease suffered by the mineworker. The negotiations of the British and Welsh Miners' Federations with the Home Office yielded significant results in that the officials were compelled to accept that there were many patient cases of serious lung disease which could not easily and directly be attributed to working with hard sandstone. After 1934 the emphasis shifted from the geological or chemical analysis of the rock to debates over the causes and progressive nature of respiratory illness in the mining communities, including the evidence of lung disease where significant silica deposits could not be traced.

After a long period of apparent stalemate in the exchanges between geologists, mining engineers and medical scientists, the Medical Research Council was faced with a rising number of claims where coal miners in the anthracite and other areas were clearly suffering from acute lung disease even where they had little contact with sandstone. In 1936-37 the MRC agreed to undertake a major new investigation into the incidence of lung diseases among coal miners in South Wales. The reports of this research team, appearing in 1942, 1943 and a final report in 1945, provided a historic reappraisal of respiratory diseases among coal miners and other colliery workers. ${ }^{62}$ The final part of the article considers the origins and early progress of this study.

\section{The MRC Study and the South Wales Miners}

The decision to undertake a fresh investigation of the coal miners' lung problems was the result of a series of campaigns and initiatives, including the efforts of mining engineers and of the coal owners themselves to embark on a scientific assessment of conditions underground. The growing uncertainties around the nature of "silicosis"

\footnotetext{
${ }^{61}$ Correspondence attached to individual case from Area No.1, case of L Owen of Banwen Colliery, who died 23 Apr. 1944 and was later certified as having died from pneumoconiosis, as per certificate 12 June 1944. His widowed mother, Eliza $\mathrm{P}$ was guided on compensation claim. Davies, Secretary of SWMF to Eliza P, 6 June 1944.
}

\footnotetext{
${ }^{62}$ Population Based Research in South Wales: The MRC Pneumoconiosis Research Unit and the MRC Epidemiology Unit, Wellcome Witnesses to Twentieth Century Medicine, vol. 13, London, Wellcome Trust, 2002, pp. 3-5.
} 


\section{"A Mere Matter of Rock"}

in coal miners also troubled the senior officials at the Home Office. In 1936 one of the senior Home Office officials visited the Mines Department to discuss the growing support for the view that symptoms of lung disease among miners were not always attributable to the presence of silica. Bannatyne, a veteran of industrial compensation and occupational injury cases, became alarmed that the publicity given to the cases in South Wales would create a "public sentiment" for new legislation with the prospect of lung diseases being included in the schedule of the Workmen's Compensation legislation without scientific (i.e. forensic) evidence of their cause. ${ }^{63}$ His colleague Edwin Field also expressed concern that the MRC investigation was about to be undertaken in an atmosphere of intense political pressure because "this was not the way in which good work was done". ${ }^{64}$ Whereas Field was sceptical about the rationale for the fresh research, pointing out that this was political and administrative rather than scientific and objective, S W Fisher, his counterpart at the Mines Department, was much more sanguine that the causes of these non-silicotic lung diseases would be uncovered by the MRC study. ${ }^{65}$

The political pressure to which these civil servants referred would have included the activities of James Griffiths, elected President of the Federation in 1934 and returned to Parliament for Llanelli with a massive majority in 1936. Griffiths pressed both the Home Secretary and Ramsay MacDonald to investigate the problems that miners with silicosis faced in winning compensation, forcing the Home Office to acknowledge the limits of medical knowledge and to ensure that fresh research was undertaken by the MRC. ${ }^{66}$ These preliminary investigations involved visits to South Wales and interviews with working miners during 1936, though the researchers found many colliers were reluctant to submit themselves to medical examination, even though their union urged the men to agree to requests from the MRC team. ${ }^{67}$ The anxieties of the miners provided eloquent testimony to their concern about the possible loss of employment if they were declared to have weak lungs. ${ }^{68}$

Another source of pressure on both the government and the Medical Research Council in the late 1930s were the press campaigns on the health problems of the Welsh miners, which clearly irritated the Home Office. These included a News Chronicle series by Louise Morgan on the accidents and diseases faced by colliers in "five fatal valleys". ${ }^{69}$ Morgan

\footnotetext{
${ }^{63}$ PRO FD1/2884, 'Pulmonary disease among coal miners', 24 Nov. 1936. E Field had visited the Mines Department from the Home Office.

${ }^{64}$ PRO FD1/2884, memo, 20.xi.36

${ }^{65}$ PRO FD1/2884, memo, 19.xi.36.

${ }^{66}$ James Griffiths, Pages from memory, London, J M Dent, 1969, p. 55. House of Commons, Hansard, 7 May 1936, cols., 1853-1854, Apr., 21 to May 8, 1935-36, 3111. Regarding the dangers of working with white lead, Bartrip has similarly noted that a few letters and some parliamentary questions from backbench MPs can be transformed into evidence of a major hazard. See Bartrip, op. cit., note 5 above, p. 85 .

${ }^{67}$ SWMF, Minutes of Council Meetings, Annual and Special Conferences 1937, Report of Executive
}

Council, 1936-1937, Cardiff, pp. 42-3, 46-7. The Federation lodges in South West Wales decided to support the investigation.

${ }^{68}$ The fear of loss of employment also deterred workers in the slate industry from claiming compensation for tuberculosis and/or silicosis, see L Bryder, 'Tuberculosis, silicosis, and the slate industry in North Wales 1927-1939', in Weindling (ed.), op. cit., note 8 above, pp. 108-26, on p. 120 .

${ }^{69}$ The five valleys were Swansea, Neath, Dulais, Amman and Gwendraeth, where silicotic miners "grow old too soon" or "galloped to death". See cuttings held in the SWCC: MNA/NUM/3/5/20, at Swansea University, South Wales. 


\section{Mark W Bufton and Joseph Melling}

passed on the large correspondence and donations, which she received in response to these articles, to Evan Williams at the Federation, seeking his guidance on "how far she could go" in depicting the attitudes of South Wales miners. ${ }^{70}$ Williams believed that this press campaign was popular with "his people" and had an excellent effect, particularly when the News Chronicle published two accounts by Williams himself, in which he took the opportunity to denounce the coal owners for their callous and indifferent response to concerns about silicosis. ${ }^{71}$ In presenting themselves at the early investigations by the Medical Research Council, the officials of the Federation were keen to emphasize that they vetted compensation claims before they were submitted to the Silicosis Medical Board. Arthur Horner, President of the South Wales Miners' Federation, told the MRC team that sick miners were mostly from the anthracite district of the western area and had been sent for X-ray by the Federation and Regional Medical Officer. Only when they received a positive diagnosis from the Federation's doctor and a certificate from the Medical Officer were they presented to the Board. Horner claimed that Federation doctors were bemused at the failure of 30 per cent of the claims before the Medical Board, which argued that the disease might not be strictly due to silicosis. ${ }^{72}$

The investigators at the Medical Research Council were well aware of the institutional and political climate in which they were considering the new study. Their preliminary report in 1936 noted that there were two distinct demands being made of their investigation: firstly, that it should provide an understanding of the health problems faced by miners in South Wales; and secondly, that it should clarify the legal and administrative grounds on which compensation could be awarded. The Council was clearly concerned that what they perceived as a scientific enquiry into the medical and health problems of miners would be obscured, or overtaken, by the political concern to resolve the urgent issue of compensation payments for diseased miners. ${ }^{73}$ These anxieties appeared to be confirmed when the Industrial Pulmonary Diseases Committee of the MRC received further preliminary reports and arranged to proceed with a major investigation at the beginning of 1938 . The Manchester Guardian was only one of a number of newspapers to greet the news in highly optimistic terms as the beginning of a new drive to eradicate silicosis. ${ }^{74}$

The press campaign and the responses of the Medical Research Council also exposed significant divisions among some of the senior figures at the Council. After a flurry of headlines announcing the imminent reduction in the prevalence of silicosis in the coalfields, Sir Edward Mellanby, Secretary of the MRC, issued a stiff rebuttal that appeared in a number of popular and broadsheet newspapers, as well as in the Lancet and British Medical

\footnotetext{
${ }^{70}$ Letter from Louise Morgan, News Chronicle, London, to Evan Williams, 21 Feb. 1936, SWCC: MNA/NUM/3/5/20. An example of the correspondence and donations can be found in letter to Evan Williams, 26 Feb. 1936, from Mrs B., Corydon, and in letter to Miss W., Brighton, from Evan Williams, 15 June 1936, both in SWCC: MNA/NUM/3/5/20. Real names have been suppressed in accordance with archive disclosure rules.

${ }^{71}$ Letter to Miss Morgan, News Chronicle, London, from Evan Williams (Secretary of the Compensation Department of the Federation), 22 Feb. 1936, SWCC:
}

MNA/NUM/3/5/20. In discussions with newspapers and medical researchers, Williams identified the 'black spots' for silicosis and respiratory cases of Tredegar, Rhymney Valley, and west of Neath.

${ }^{72}$ PRO FD1/2884, 'Medical Research Council: Committee on Industrial Pulmonary Disease', meeting held on 17 June 1936.

${ }^{73}$ PRO FD1/2884, 'Medical Research Council: Committee on Industrial Pulmonary Disease', meeting held on 17 June 1936, p. 2.

74 'Eradicating silicosis: a hopeful report: a big reduction soon', Manchester Guardian, 27 Jan. 1938. 


\section{"A Mere Matter of Rock"}

Journal. ${ }^{75}$ It is worth quoting this disclaimer, which noted that:

During the past week several newspapers have published inaccurate accounts of the progress of the investigation into silicosis in the South Wales coalfield which is being promoted by the [MRC] ... These include a statement attributed to "a member of the pulmonary Diseases Board" (apparently meaning one of the investigators working under the direction of the Committee), to the effect that the results of the inquiry will make possible an immediate reduction of over eighty per cent in the incidence of silicosis in the anthracite coalfield; the facts are that the investigation is still in an early stage; that the results cannot yet be assessed; and that no such opinion as that purporting to be quoted has been formed. No interview has been given to the press, and the alleged statement has not been made by the investigators. ${ }^{76}$

Mellanby was concerned that the newspaper coverage would invite popular expectations of a rapid decrease in silicosis across South Wales.

There may have also been something of a personal struggle between Mellanby and D'Arcy Hart, who was equally appalled that the Daily Mail, as one of the "chief perpetrators" of these claims, had identified the MRC investigators by name. ${ }^{77}$ Hart was also annoyed by Mellanby's public refutation of the account since the MRC Secretary had advised a Daily Herald reporter to consult him personally for details of the enquiry. Hart complained to a senior colleague at the MRC that he had not been consulted about the letter and requested a meeting with Mellanby on "the whole matter of publicity", since Hart believed that he should be the main contact with the press on questions relating to the MRC study. ${ }^{78}$ These exchanges indicate that the pursuit of scientific evidence and its presentation to the public was coloured by the micro-politics of the MRC and the promotion of personal reputation as well as the protection of scientific rigour in the face of intense political and press speculation at the outcome of the investigation. These professional rivalries, and the personal investment in scientific reputation which they reveal, formed one part of, and were also informed by, a wider set of struggles over the uses to be made of evidence in the protection and compensation of miners during the period reviewed in this article. $^{79}$

\section{Conclusions}

Much of the historical debate over the regulation of respiratory disease in British industry has been concerned with the ways in which the Home Office and its

\footnotetext{
75 'Silicosis inquiry in South Wales: a disclaimer', Manchester Guardian, written by Mellanby to the editor, 7 Feb. 1938; 'Silicosis inquiry in South Wales: a disclaimer', Br. med. J., 5 Feb. 1938; 'Our readers views: Silicosis inquiry in South Wales: an authoritative statement of the position: results cannot yet be assessed', Western Mail, 3 Feb. 1938.

${ }^{76}$ PRO FD1/2886, 'Silicosis inquiry in South Wales: a disclaimer', 1 Feb. 1938. 'Silicosis Inquiry: 400 miners examined at Ammanford', South Wales Post, 8 Feb. 1938.

${ }^{77}$ PRO FD1/2886, Letter to Dr Lansborough Thomson from P D'Arcy Hart, 2 Feb. 1938.
}

\footnotetext{
${ }^{78}$ PRO FD1/2886, Letter to Dr Lansborough Thomson from P D'Arcy Hart, 8 Feb. 1938. Hart commented: "I feel I must, if I am to have the responsibility of seeing pressmen, have authority to make as well as to refuse statements"

${ }^{79}$ For professional rivalries in a different medical sphere, see Mark W Bufton, David F Smith and Virginia Berridge, 'Professional ambitions, political inclinations, and protein problems: conflict and compromise in the BMA Nutrition Committee 1947-1950', Med. Hist., Oct. 2003, 47: 473-92.
} 


\section{Mark W Bufton and Joseph Melling}

senior medical experts responded to evidence of hazardous conditions in the workplace. Discussions of occupational illness in the interwar years have been dominated by three kinds of narrative. Firstly, a critical assessment of the Home Office as inclined to safeguard the interests of industry and protect its competitive position in difficult trading conditions rather than seize the initiative in promoting health and safety at work where evidence was inconclusive. Secondly, a more benign view of the Home Office and its advisers as honest brokers who sought to balance the competing claims of different interest groups and to meet the legitimate claims of organized labour wherever possible, even though the latter were often more concerned with compensation rewards than preventive regulation. Thirdly, an account of occupational health which views the hazards facing workers as only one aspect of a wider class oppression and struggle in which there remained hard choices of idleness and unemployment even when compensation was provided.

It is possible to find some support for each of these interpretations in the sources we have used for our analysis of silicosis schemes in this period. In particular, the major associations that represented organized labour claimed important victories in their dealings with politicians and civil servants in these years. ${ }^{80} \mathrm{We}$ have argued, however, that the rival interpretations of the Home Office's relationship with organized interests and its responses to evidence of industrial hazard do not provide us with a compelling explanation of the complex array of calculations and pressures which resulted in silicosis regulation and ultimately a fresh investigation by the MRC. In particular, we question the interpretation provided by Bartrip that the Home Office responded effectively when scientific evidence of a hazard was demonstrated, together with practical techniques for its eradication.

Our analysis has suggested that the personnel of the Home Office were eminently reasonable and conscientious in seeking to discover consensual solutions to the complex problem of respiratory health. Their professional and ethical conduct was framed, however, within both intellectual and institutional boundaries which ensured that the pervasive dust hazards faced by the largest workforce affected were largely occluded from serious consideration until the closing years of our period. By 1918 the fundamental problem of respiratory health in the workplace was perceived as largely one of silica poisoning, where dust was inhaled in concentrated amounts over a lengthy period of time. Hazardous sandstone dust was associated with a relatively narrow range of mining, cutting, grinding and clay-baking operations that posed a severe threat to a few thousand workers. At least as important as the preoccupation with the distinctive hazard of silica rock to the industrial workforce, were the institutional arrangements for legal compensation underpinned by scientific orthodoxy. The small refractories industry remained the model for regulation across a range of industries, though it was soon apparent that the requirement in the 1928 Various Industries Scheme for the miner to demonstrate a substantial period of recent employment in working rock with high silica content did not permit compensation of numerous miners with severe lung disease.

\footnotetext{
${ }^{80}$ MFGB, Annual Conference July 1935, pp. 43, 175 , for example. The SWMF heard that while "Governments move slowly in these matters" the 1934 Silicosis Scheme was the fruit of
}

"many years of effort" and signalled a radical
change of view from 1928 when it had been
thought that silicosis "could not be contracted in
a coal mine". 


\section{"A Mere Matter of Rock"}

Having carefully built an intricate system of preventive, surveillance and compensation arrangements in consultation with employers, workers and others, the Home Office appeared reluctant to contemplate a radical shift in the paradigm of regulation. Relaxations of the rules in 1931 and particularly in 1934 were secured only after considerable pressure and the investment of union funds in lengthy legal conflicts. Even the appointment and conduct of the MRC study in 1936-38 was overshadowed by the controversy over the refusal of compensation to diseased coal miners. For British governments and their administrative personnel were anxious to avoid their provisions for industrial injury being drawn on to the complex, contested terrain of labour contracts and into the battles over minimum hours and wages which had culminated in the bitter and prolonged coal dispute of 1926. They were well aware that iron and steel employers, as well as the coal masters, were determined to prevent the inclusion of such areas as foundry work in the silicosis schemes. It was the determined campaigning by the Miners' Federations across Britain and in South Wales which challenged British governments not only to reconsider the predicament of colliery workers but also to reappraise the scientific rules of the compensation game, for, as Bloor has noted, the mining unions did not "passively receive and assimilate scientific information". 81

In emphasizing the macro politics of British government as a necessary context in which to understand the regulation of occupational disease, we have also attempted to encompass the micro world of individual claims and the patient-physician relationship which Dembe and others have explored. For, if the value of class analysis lies in the capacity to relate workplace struggles to the collective politics of Welsh mining communities, its limitations can be detected in the tendency to equate the interests of miners with the more radical class agenda of particular leaders. We have suggested that individuals sometimes sought to negotiate their own solution to the problem of bad lungs, while in many other cases the local union lodges were involved in pressing applications. It seems likely that sympathetic doctors were diagnosing some cases of silicosis on a speculative basis, suggesting the possibility of silicosis in miners with respiratory disorders. In examining the fragmentary documents which survive for particular applications we recognize that these sources contributed to the particular patient histories which were framed according to the requirements of the different schemes. The individual's account of his industrial history had been recognized as an essential feature of accurate diagnosis in occupational health for many years. During the interwar years the predicament of the individual miner became part of a larger political and intellectual struggle over the responsibility for ill health in the workplace.

These conflicts were not engendered simply by a sense of class injustice. The Federation and other unions were also riven by political sectarianism and occasional leadershipmember conflicts over slow progress in tackling silicosis. It was the threat of disaffection among the South Wales miners that contributed to the dramatic decision in 1943 to subordinate silicosis to pneumoconiosis as the most important hazard facing British

\footnotetext{
${ }^{81}$ Bloor, 'The South Wales Miners' Federation', op. cit., note 12 above, p. 135. Their influence may be contrasted with the apparent weakness of the trade unions in the framing of the 1931
}

asbestos industry regulations. See Nick Wikeley, 'The asbestos regulations 1931: a licence to kill?', J. Law Soc., 1992, 19: 365-78, on pp. 370-2. 


\section{Mark W Bufton and Joseph Melling}

miners. ${ }^{82}$ In 1946 the Inspector of Mines, Brian Spencer, claimed that dust suppression methods had effectively tackled the hazard of coal dust and that the "Scourge of the Welsh [had] been vanquished" ${ }^{83}$ Though Spencer's article did draw attention to the prominence of the Welsh collieries in the transformation of government policy during the previous two decades, his assessment seriously underestimated the chronic disease of pneumoconiosis which continued to disable those affected in the post-war period.

\footnotetext{
${ }^{82}$ The three Medical Research Council Reports were responsible for the definitive classification of chronic pulmonary disease caused by coal dust inhalation. Medical Research Council, Chronic pulmonary disease in South Wales coalminers: I. Medical studies, London, HMSO, 1942; Medical Research Council, Chronic pulmonary disease in South Wales coalminers: II. Environmental studies, London,
}

HMSO, 1943; Medical Research Council, Chronic pulmonary disease in South Wales coalminers: III. Experimental studies, London, HMSO, 1943.

${ }^{83}$ Brian Spencer, 'Scourge of the Welsh has been vanquished: deadly dust cloud is lifting from pits', The Welsh cutter: a newspaper about mining, 5 Aug. 1946. This newspaper was published by the Ministry of Fuel and Power. 